\title{
Phosphorus Removal from Wastewater in Johkasou Sewage Treatment Tank by Electro-coagulation
}

\author{
Shu Wang, Fangmin Li, Zhangyong Liu, and Guoping Liu
}

\begin{abstract}
Orthogonal experimental plan was used to explore the effect of aeration rate, electrolysis time, and current density on the total phosphorus (TP) removal of sewage from purification tank (Johkasou). The results showed that the removal efficiencies of total phosphorus in an anode-cathode-anode electrolytic cell increased by from $3.4 \%$ to $22.6 \%$ than that of an anode-cathode electrolytic cell. For the anode-cathode-anode electrolytic cell, the TP concentration of effluent could reach below $1 \mathrm{mg} / \mathrm{L}$ (discharge standard for effluent) with a TP removal rate above $95.9 \%$ under the condition of electrolysis time of 60 mins or current density of 4 $\mathrm{mA} \cdot \mathrm{cm}^{-2}$. Whereas the anode-cathode electrolytic cell must require a combination with any two of the above three experimental factors at high levels to achieve the discharge standard, and the TP removal rates were more than $92.6 \%$. Aeration improved the phosphorus removal rate in the electrolysis apparatus. Fourier transform infrared spectroscopy (FTIR) analysis showed that the precipitate of electro-coagulation was a mixture of hydroxyl iron phosphate and iron phosphate. The phosphorus of the sewage in the Johkasou could be effectively removed through sludge discharge.
\end{abstract}

Index Terms-Electro-coagulation, electrolysis, Johkasou, total phosphorus, removal rate.

\section{INTRODUCTION}

Johkasou originated in a rural area of Japan. It was a small-scale domestic purification tank device used to treat sewage produced from residential daily life that lack public wastewater treatment facilities. The device uses an anaerobic/anoxic/oxic $\left(\mathrm{A}_{2} / \mathrm{O}\right)$ process. It is composed of anaerobic, anoxic and aerobic chambers. Microorganisms attached to the fillers are used to remove organic matter, total nitrogen and total phosphorus (TP) from the sewage. An anaerobic ilter bed-contact aeration process was used in Johkasou. The removal rates for the organic pollution load (chemical oxygen demand (COD), biological oxygen demand $\left(\mathrm{BOD}_{5}\right)$ ) and $\mathrm{NH}_{4}{ }^{+}-\mathrm{N}$ in the treated effluent can exceed $95 \%$, and the removal rates of total nitrogen ranges from 65 to $80 \%$ in Johkasou [1]. However, the TP removal efficiency was often poor [1], [2]. Therefore, a more efficient process for phosphorus removal from the Johkasou effluent is needed.

Manuscript received October 20, 2015; revised January 14, 2016. This work was supported financially by the Program for Outstanding Middle-aged and Young Innovation Team of Higher Education Institutions in Hubei Province (T201404).

S. Wang and F. Li are with the School of Chemistry and Environmental Engineering, Yangtze University, Jingzhou, 434023, China (e-mail: 452953504@qq.com, lifangmin@yeah.net, 792407981@qq.com).

Z. Liu and G. Liu are with the Engineering Research Center of Ecology and Agricultural Use of Wetland, Ministry of Education. Jingzhou, 434025, China.
The most commonly used methods for phosphorus removal are chemical coagulation, electro-coagulation, and microbiological. Because of a large amount of coagulants required for chemical coagulation, it is expensive, sludge disposal is difficult, and secondary pollution may occur [3]. Biological phosphorus removal procedure is achieved by anaerobic phosphorus release, aerobic phosphorus uptake, and sludge discharge. This process is lengthy, and biochemical environment requirements are stringent, however the efficiency of phosphorus removal is typically less than $30 \%$ [4]. Electro-coagulation has many advantages, such as the intellectualized operation of the electrolys is device without the use of chemicals, small amounts of sludge, and high phosphorus removal rate [3]-[6]. Therefore, it has received considerable research attention. Electro-coagulation technology removes phosphorus by generating precipitates from the coagulation that occurs between the metal ions produced from the anode and $\mathrm{PO}_{4}{ }^{3-}$ insewageunder an external current. The electrode material, current density, electrode plate spacing and the influent phosphorus concentration have significant effects on phosphorus removal [7]-[10], and inactivation of the anode plate appears to various degrees [11].

To improve the efficiency of TP removal from sewage and to reduce passivation phenomenon, anode-cathode-anode electrolytic cells were used in this study and the sewage from the aeration tank of the Johkasou was collected. The effects of aeration rate, current time, current density, and test factors on phosphorus concentration and TP removal rate were studied.

\section{MATERIALS AND METHODS}

\section{A. Experimental Device}

The schematic diagram of the Electro-coagulation device is shown in Fig. 1. The effective volume of the electrolytic cell was $7 \mathrm{~L}$. Both cathode and anode were iron plates with a size of $20 \mathrm{~cm} \times 15 \mathrm{~cm}$ (thickness: $1 \mathrm{~mm}$ ). These were fixed at the center of the electrolytic cell, and the effective size of the plates immersed in water was $17 \mathrm{~cm} \times 15 \mathrm{~cm}$. Prior to the experiment, their electrode plates were briefly immersed into dilute hydrochloric acid to remove the surface rust and oxide layer, and well washed with deionized water.

\section{B. Experimental Design}

The current density was fixed at $2 \mathrm{~m} \mathrm{~A} \cdot \mathrm{cm}^{-2}$ and the distance between anode and cathode was varied at 1.5, 3.0, 4.5 and $6.0 \mathrm{~cm}$. The TP concentrations were then measured after 5, 10, 15, 20, 25, 30, and 40 mins electrolysis, respectively, and the corresponding removal rates were 
calculated. Three additional factors, i.e., aeration rate, electrolysis time and the current density, were tested with three levels per each factor. The orthogonal experimental design is shown from Table I. The electro-coagulation experiments were carried out in an anode-cathode cell and in an anode-cathode-anode electrolysis cell, respectively. The distance between the two electrode plates was $3.0 \mathrm{~cm}$. The aeration rate, electrolysis time, and current density were controlled by a gas flows witch, time controls witch, and by adjusting the current, respectively. At the end of the test, the electrode plates were removed and the electrolyte solution was mixed. Part of the liquid was filtered by vacuum filtration and the filtrate was used to analyze the TP in the test liquid by $\mathrm{K}_{2} \mathrm{~S}_{2} \mathrm{O}_{8} \quad$ digestion-coloration-spectrophotometer. The precipitates were washed with distilled water, dried at $105^{\circ} \mathrm{C}$, and dispersed in spectroscopic pure $\mathrm{KBr}$. The spectral scan was carried out on a FTIR spectrophotometer (Nicolet 6700 type, Nicolet Co. USA).

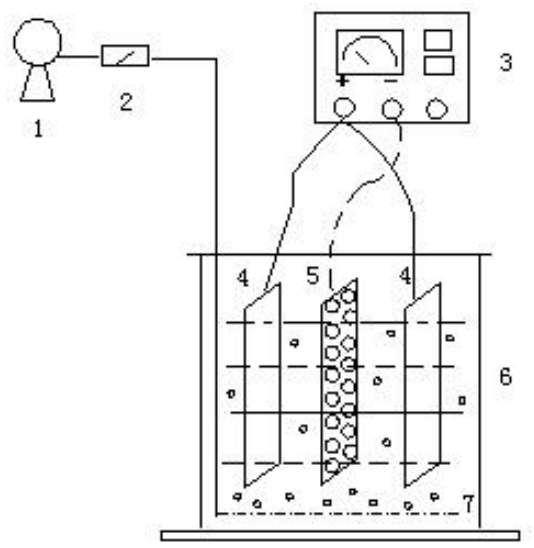

Fig. 1. Schematic diagram of the electrocoagulationdevice:1-gas pump; 2-gasflow meter; 3-DC power supply; 4-anode; 5-cathode; 6-electrolytic cell; 7-aerator.

\section{RESULTS AND ANALYSIS}

\section{A. Effect of Electrode Plate Spacing on TP Removal}

The effect of electrode plate spacing and electrolysis time on TP removal rate is shown from Fig. 2. There were significant differences in TP removal rate due to the effects of different electrode plate distances and minutes (5-25 mins) of electrolysis. The TP removal rate for each electrode plate distance was in the following order: $4.5 \mathrm{~cm}>3.0 \mathrm{~cm}>1.5 \mathrm{~cm}>6.0 \mathrm{~cm}$. The removal rate of each treatment was significantly increased with prolonging electrolysis time. When the electrolysis time exceeded30mins, the effect of difference between electrode plate distances on the removal rate was small. When the electrode plate distance was small, because of the ineffective diffusion of the ions between the two electrode plates, the over-potential situation was caused by the concentration polarization. It affected the phosphorus removal. However, the resistance between the two electrode plates also increased with the increasing electrode plate distance. In order to maintain the same current density, the electrolysis voltage should be increased and the energy consumption of the system was also increased, so when the electrolysis time was over 30 mins, the appropriate plate distance ranged from 3.0 to $4.5 \mathrm{~cm}$ to save energy.
TABLE I: PLAN OF ORTHOGONAL EXPERIMENT DESIGN

\begin{tabular}{|c|c|c|c|}
\hline \multirow[b]{2}{*}{ Run } & \multicolumn{3}{|c|}{ Experimental factors } \\
\hline & $\begin{array}{l}\text { Aeration rate } \\
\left(\mathrm{L} \cdot \mathrm{h}^{-1}\right)\end{array}$ & $\begin{array}{l}\text { Electrolysis time } \\
\text { (min) }\end{array}$ & $\begin{array}{l}\text { Current density } \\
\left(\mathrm{mA} \cdot \mathrm{cm}^{-2}\right)\end{array}$ \\
\hline I & $1(0)$ & $1(15)$ & $1(1)$ \\
\hline II & $1(0)$ & $2(30)$ & $2(2)$ \\
\hline III & $1(0)$ & $3(60)$ & $3(4)$ \\
\hline IV & $2(90)$ & $1(15)$ & $2(2)$ \\
\hline $\mathrm{V}$ & $2(90)$ & $2(30)$ & $3(4)$ \\
\hline VI & $2(90)$ & $3(60)$ & $1(1)$ \\
\hline VII & $3(180)$ & $1(15)$ & $3(4)$ \\
\hline VIII & $3(180)$ & $2(30)$ & $1(1)$ \\
\hline IX & $3(180)$ & $3(60)$ & $2(2)$ \\
\hline
\end{tabular}

\section{B. Effect of Anode-Cathode Electrolytic Cell on TP Removal Rate}

The anode-cathode electrolytic cell was composed of one cathode plate and one anode plate. TP concentrations and TP removal rates in the treated sewage after testing with different aeration rates, electrolysis times and current densities were shown from Table II. The effluent TP concentrations after three types of treatments meet the Level 1B discharge standard for a municipal wastewater treatment plant $(\leq 1 \mathrm{mg} / \mathrm{L})$. That is, the treatments with two of three factors at high levels were produced the above favorable result (treatment III, VII, IX). When the aeration rateswere $180 \mathrm{~L} \cdot \mathrm{h}^{-1}$ and $90 \mathrm{~L} \cdot \mathrm{h}^{-1}$, the non-significant differences in the average removal rate were $88.5 \%$ and $86.1 \%$, respectively. And these values were significantly greater than the treatment without aeration (68.4\%). The higher values resulted from the increasing dissolved oxygen due to the aeration process that rapidly oxidized the $\mathrm{Fe}^{2+}$ into $\mathrm{Fe}^{3+}$ from the anode and promoted the formation of $\mathrm{FePO}_{4}$ precipitates. At the same time, diffusion was accelerated by means of the aeration that kept the reaction system in a strong turbulent state. Probability of ion contact with phosphate increased, and phosphorus removal was accelerated [12]. When the electrolysis times were 15, 30 and 60 mins, the average removal rates were $69.0 \%$, $80.7 \%$ and $93.3 \%$, respectively. The results showed a significantly increased in the removal rate with electrolysis time increasing. When the current densities were 1,2 , and 4 $\mathrm{mA} \cdot \mathrm{cm}^{-2}$, the average removal rates were $66.6 \%$, $84.9 \%$ and $91.4 \%$, respectively. This demonstrated that the TP removal rate also increased with the increasing current density. The amounts of $\mathrm{Fe}^{2+}$ and $\mathrm{Fe}^{3+}$ produced from the electrolysis on the anodeplateper unit time increased with the increase in current density, and the amount of multi nuclear hydroxyl complex was also increased accordingly. This favored the formations of coagulum and $\mathrm{Fe}(\mathrm{OH})_{3}$ and $\mathrm{FePO}_{4}$ precipitates, and significantly improved phosphorus removal [7]. Therefore, the decreasing order of efficacy for the factors affecting the removal rate was as follows: current density >electrolysis time >aeration rate. Maximum TP removal efficiency was reached under the following conditions: aeration rate of $180 \mathrm{~L} \cdot \mathrm{h}^{-1}$, electrolysis time of 60 mins, current density of $4 \mathrm{~mA} \cdot \mathrm{cm}^{-2}$ ).

\section{Effect of Anode-Cathode-Anode Electrolytic Cell on TP Removal Rate}

For the anode-cathode-anode electrolytic cell composed of one cathode plate and two anode plates, five treatments which high levels of electrolysis time or current density would be 
sufficient allowed the effluent TP concentration to meet the Level 1B discharge standard for municipal wastewater treatment plants $(\leq 1 \mathrm{mg} / \mathrm{L})$ (Table II). When the levels of the three test factors were at low, medium and high, the average removal rates of the anode-cathode-anode electrolytic cell were relative higher than that of anode-cathode electrolytic cell by $17.6 \%-22.6 \%, 6.2 \%-12.4 \%$, and $3.4 \%-5.6 \%$, respectively. This showed a significant increase in the removal rate. As the electrolysis time and the current density increased, the surface of the anodeplate was passivated due to the presence of anoxide film. An additional anodeplate delayed the passivation, thus improved the coagulation effect.

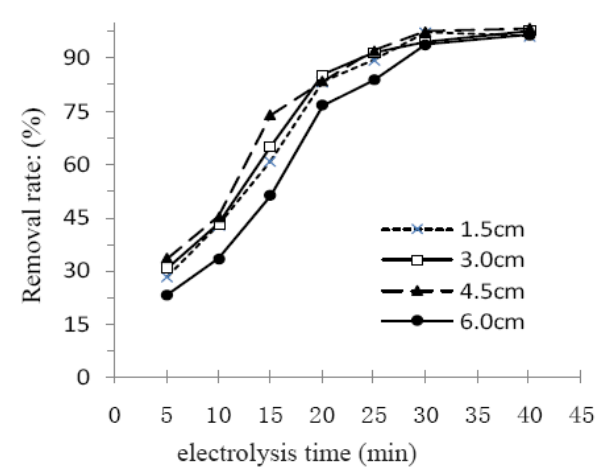

Fig. 2. Effect of plate spacing on TP removal rate.

TABLE II: REMOVAL EFFICIENCIES OF TP IN TWO TYPES OF ELECTROLYTIC

\begin{tabular}{|c|c|c|c|c|c|c|}
\hline \multicolumn{7}{|c|}{ Cells } \\
\hline $\begin{array}{c}\mathrm{Ru} \\
\mathrm{n}\end{array}$ & \multicolumn{3}{|c|}{ 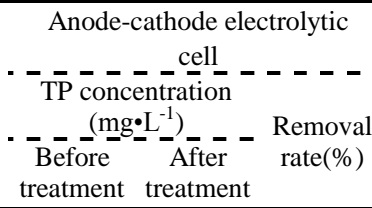 } & \multicolumn{3}{|c|}{$\begin{array}{l}\text { Anode-cathode-anode } \\
\text { electrolytic cell } \\
\Gamma \mathrm{P} \text { concentration } \\
\left(\mathrm{mg} \cdot \mathrm{L}^{-1}\right)\end{array}$} \\
\hline I & 9.54 & 6.51 & 31.8 & 13.42 & 4.92 & 63.3 \\
\hline II & 10.86 & 2.42 & 77.7 & 13.70 & 1.42 & 89.6 \\
\hline III & 10.95 & 0.48 & 95.6 & 11.31 & 0.39 & 96.6 \\
\hline IV & 11.69 & 2.03 & 82.6 & 13.75 & 2.16 & 84.3 \\
\hline V & 11.20 & 1.58 & 85.9 & 13.88 & 0.43 & 96.9 \\
\hline VI & 11.82 & 1.21 & 89.8 & 13.46 & 0.51 & 96.2 \\
\hline VII & 12.15 & 0.90 & 92.6 & 14.08 & 0.58 & 95.9 \\
\hline VIII & 9.91 & 2.14 & 78.4 & 13.88 & 2.00 & 85.6 \\
\hline IX & 11.86 & 0.66 & 94.4 & 14.13 & 0.48 & 96.6 \\
\hline
\end{tabular}

When aeration rates were applied at $90 \mathrm{~L} \cdot \mathrm{h}^{-1}$ and $180 \mathrm{~L} \cdot \mathrm{h}^{-1}$, respectively, there was only a small difference between the average removal rates $(92.5 \%$ and $92.7 \%)$, which were both higher than that of the treatment without aeration $(83.2 \%)$. And this was similar with the conclusion in the anode cathode electrolytic cell. When the electrolysis times were 15 , 30 and 60 mins, the average removal rates reached $81.2 \%$, $90.7 \%$ and $96.5 \%$, respectively, indicating that the removal rates significantly increased compared with the anode-cathode electrolysis cell. When the current densities were 1,2 , and $4 \mathrm{~m} \mathrm{~A} \cdot \mathrm{cm}^{-2}$, the average removal rates increased to $81.7 \%, 90.2 \%$, and $96.4 \%$ respectively. This results showed that the removal rates increased with the current densities. Therefore, in the ranges of the test factors, the order of this electrolytic cell on the removal rate was as follows: electrolysis time>current densities>aeration rate. This result was slightly different from that of the anode-cathode electrolytic cell. The maximum TP removal efficiency occurred under the optimum conditions: aeration rate of $180 \mathrm{~L} \cdot \mathrm{h}^{-1}$, electrolysis time of $60 \mathrm{mins}$, and current density of $4 \mathrm{~mA} \cdot \mathrm{cm}^{-2}$.

\section{FTIR Analysis of Electro-coagulum}

The FTIR spectrum of the electro-coagulum produced from the iron electrode plate in sewage is shown from Fig. 3. The broad absorption peak was at $3351.7 \mathrm{~cm}^{-1}$, and could be the stretching or bending vibration of the $-\mathrm{OH}$ group in the precipitates and the crystalline water or the $-\mathrm{OH}$ group in hydroxyl iron phosphate [13]. The absorption peak was at $1653.3 \mathrm{~cm}^{-1}$ wasassigned to the stretching vibration of $\mathrm{NH}_{4}^{+}$ [14] in the coagulum of ammonium-iron phosphate. The strong absorption peak was at $1009.8 \mathrm{~cm}^{-1}$ and was assigned to the bending vibration of $\mathrm{Fe}-\mathrm{O}-\mathrm{Pgroup}$ in the iron phosphate molecule [14]. The dominant precipitate color was light yellow when electrolysis time was short, and red-brown when electrolysis time was long. The results indicated that the electrolytic precipitate was a mixture of light-yellow iron phosphate and a red-brown hydroxyl iron phosphate. The hydroxyl iron phosphate has good adsorption and coagulation, and can help to improve the rate of phosphorus removal from sewage. Therefore, longer electrolysis time lead to better effect of coagulation on phosphates.

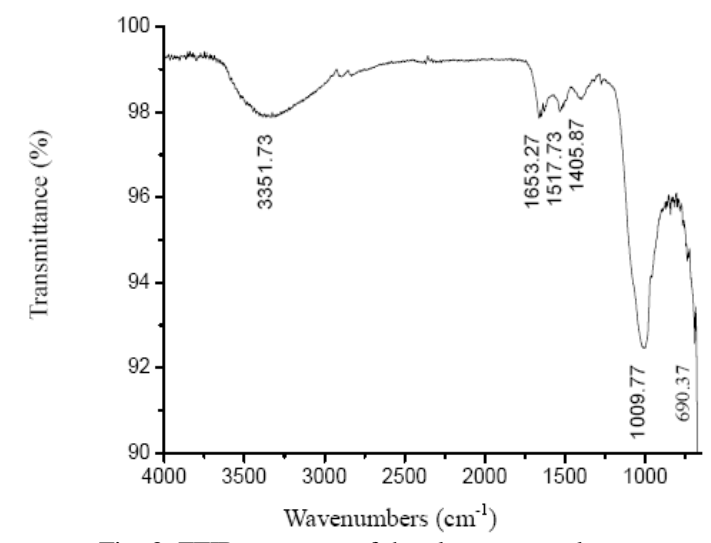

Fig. 3. FTIR spectrum of the electro-coagulum.

\section{CONCLUSIONS}

1) The TP removal rate of anode-cathode-anode electrolytic cell was significantly greater than the anode-cathode electrolytic cell. When the three test factors (aeration rate, electrolysis time and current density) were at low, medium and high levels, the increased percents of TP removal rates were $17.6 \%-22.6 \%, 6.2 \%-12.4 \%$, and $3.4 \%-5.6 \%$, respectively.

2) The order of the importance of test factors on the TP removal rate for two electrolytic cells was different. For the anode-cathode-anode electrolytic cell, it was as follow: electrolysis time >current density >aeration rate; but for the anode-cathode electrolytic cell, it was: current density >electrolysis time>aeration rate.

3) FTIR analysis showed that the electro-coagulum was a mixture of red-brown hydroxyl iron phosphate and light-yellow iron phosphate. When electrolysis time was short, the iron phosphate precipitate was dominant; and when electrolysis time was long, the hydroxyl iron 
phosphate was dominant.

\section{ACKNOWLEDGMENT}

The authors would like to acknowledge the assistance and contribution of team members from Collaborative Innovation Center of Healthy Pig Farming in Hubei Province.

\section{REFERENCES}

[1] H. Ohmori, T. Yahashi, Y. Furukawa, K. Kawamura, and Y. Yamamoto, "Treatment performance of newly developed Johkasous with membrane separation," Water Sci. \& Technol. vol. 41, pp. 197-204, 2000.

[2] K. Bao, J. Gao, Z. Wang, J. Zhou, and R. Zhang, "Factors influencing domestic sewage treatment with modified Merger Johkaso," Water Resour. Protect., vol. 28, pp. 69-73, 2012.

[3] M. Pidou, L. Avery, T. Stephenson, P. Jeffrey, S. A. Parsons, S. Liu et al., "Chemical solutions for grey water recycling," Chemosphere, vol. 71, pp. 147-155, 2008.

[4] E. Vaiopoulou, P. Melidis, and A. Aivasidis, "An activated sludge treatment plant for integrated removal of carbon, nitrogen and phosphorus," Desalination, vol. 211, pp. 192-199, 2007.

[5] S. Vasudevan, J. Lakshmi, J. Jayaraj, and G. Sozhan, "Remediation of phosphate-contaminated water by electro coagulation with aluminium, aluminum alloy and mild steel anodes," J. of Hazard. Mater, vol. 164, pp. 1480-1486, 2009.

[6] K. Bani-Melem and E. Smith, "Grey water treatment by a continuous process of an electro coagulation unit and a submerged membrane bioreactor system," Chem. Engin. J., vol.198/199, pp.201-210, 2012.

[7] Ş. İrdemez, N. Demircioğlu, Y. Ş. Yıldız, and Z. Bingül, "The effects of current density and phosphate concentration on phosphate removal from wastewater by electro coagulation using aluminum and iron plate electrodes," Separ. And Puri. Technol., vol. 52, pp. 218-223, 2006.

[8] F. Llhan, U. Kurt, O. Apaydin, and M. T. Gonullu, "Treatment of leachate by electro coagulation using aluminum and iron electrodes," $J$. of Hazard. Materi., vol. 154, pp. 381-389, 2008.

[9] K. Bensadok, N. E. Hanafi, and F. Lapicque, "Electrochemical treatment of dairy effluent using combined $\mathrm{Al}$ and $\mathrm{Ti} / \mathrm{Pt}$ electrodes system," Desalination, vol. 280, pp. 244-251, 2011.
[10] E. Lacasa, P. Caňizares, C. Sáez, F. J. Fernández, and M. A. Rodrigo, "Electrochemical phosphates removal using iron and aluminium electrodes," Chem. Engin. J., vol. 172, pp. 137-143, 2011.

[11] A. Ciblak, X. Mao, I. Padilla, D. Vesper, I. Al-Shawabkeh, and A. N. Alshawabkeh, "Electrode effects on temporal changes in electrolyte $\mathrm{pH}$ and redox potential for water treatment," J Environ Sci Health A:Tox Hazard Subst \& Environ Eng., vol. 47, pp. 718-726, 2012.

[12] M. J. Yu, Y. H. Ku, Y. S. Kim, and G. N. Myung, "Electro coagulation combined with the use of an intermittently aerating bioreactor to enhance phosphorus removal," Environ. Technol., vol. 27, pp 483-491, 2006.

[13] Z. Yan, Q. He, T. Long, and H. Zhang, "Mechanisms of phosphorus removal by aerated filtration with porous iron-rich media (in Chinese)," Chin. J. of Environ. Engin., vol. 4, pp. 1305-1308, 2010.

[14] S. J. Parikh, F. N. D. Mukome, and X. Zhang, "ATR-FTIR spectroscopic evidence for biomolecular phosphorus and carboxyl groups facilitating bacterial adhesion to iron oxides," Collo. \& Surf. B: Biointer., vol. 119, pp. 38-46, 2014.

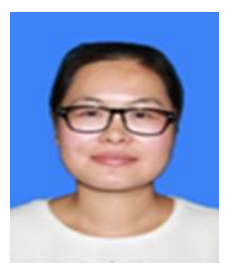

Su Wang was born in China, 1990. She received her B.Sc. degree from Hubei Engineering University, China, in 2013. She is currently carrying out her M. D studies at Yangtze University on the subject of treatment and reuse of piggery wastewater.

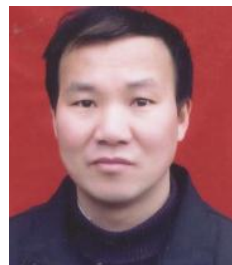

Fangmin Li was born in China, 1965. He obtained $\mathrm{Ph}$. D. from School of Resources and Environment, South China Agricultural University in December, 2004. He is a senior member of Environmental Science Society of China. His major field of study is rural wastewater treatment. He is currently a professor of soil and environmental science at the Yangtze University, Jingzhou, China. He cooperated with professor Y. Sakurai at Ehime University, Matsuyama, Japan, from July 2007 to June 2008 as a visiting scholar. Since 2012, he worked in research about rural domestic wastewater treatment facility and its purified technology. 